\title{
Editorial \\ Introduction to Special Issue: Brand Equity, Satisfaction, and Word of Mouth
}

\author{
María Eugenia Ruiz-Molina *, Irene Gil-Saura (D) and Gloria Berenguer-Contrí
}

check for

updates

Citation: Ruiz-Molina, M.E.; Gil-Saura, I.; Berenguer-Contrí, G. Introduction to Special Issue: Brand Equity, Satisfaction, and Word of Mouth. Sustainability 2021, 13, 12738. https: / / doi.org/10.3390/ su132212738

Received: 14 November 2021 Accepted: 16 November 2021 Published: 18 November 2021

Publisher's Note: MDPI stays neutral with regard to jurisdictional claims in published maps and institutional affiliations.

Copyright: (c) 2021 by the authors. Licensee MDPI, Basel, Switzerland. This article is an open access article distributed under the terms and conditions of the Creative Commons Attribution (CC BY) license (https:// creativecommons.org/licenses/by/ $4.0 /)$.
Marketing Department, Universitat de València, 46022 Valencia, Spain; irene.gil@uv.es (I.G.-S.); gloria.berenguer@uv.es (G.B.-C.)

* Correspondence: M.Eugenia.Ruiz@uv.es
The COVID-19 pandemic has generated an incredible change in the global economy that will likely have long-term consequences on consumer behavior, markets, business models, market regulation, and public policies, among others [1,2]. We are only at the beginning of seeing these effects, and this new scenario offers opportunities to articulate research in the area of marketing aligned with the urgency of recovering customer trust and reactivating sales [3]. The five contributions presented in this Special Issue, "Brand Equity, Satisfaction, and Word of Mouth", aim at being incorporated into the dynamics of methodological and thematic innovation in marketing, in reply to some of the research priorities that, due to their potential, are presented today as opportunities and preferential research domains, in the highly complex scenario depicted after the COVID-19 outbreak.

In this context, three of the papers of this Special Issue (contribution numbers 4, 5, 6) focus on the study of service companies, a highly threatened sector in the post-COVID-19 era. In the current health crisis environment, the way in which services are experienced by customers has changed substantially. The pandemic and the advances in technology have changed the way customers engage with businesses before, during, or after purchase. As a result, the importance of research in services and the need for new knowledge related to this field has never been greater. These companies have been strongly affected by the restrictions imposed by the pandemic; therefore, in order to counteract the dramatic fall in their demand, it is necessary to quickly identify levers that stimulate and drive their activation [4]. Marín-García, Gil-Saura, Ruiz-Molina, and Berenguer-Contri [5] focus on retailing, considering that sustainability emerges as a key element to build the development of competitive advantages for businesses. In the dynamic and turbulent environment in which retailers operate, sustainable practices are posited as an opportunity for their progress and survival. Through this article, it is intended to advance the nature and dimensions of this construct and examine its influence on store equity and consumer satisfaction. The results show the importance of sustainability and brand equity in the development of consumer satisfaction in retailing. All of this points to the need to move towards more sustainable business models. Lee and Kim [6] focus on the field of tourism. The importance of non-face-to-face tourism is growing due to the impact of COVID-19, and VR (virtual reality) is attracting attention as a solution to this need. This research investigates the antecedents of utilitarian and hedonic values based on the experience of VR tourism and identifies the relations between values and the user visit intention. The results of the research show the antecedents of the utilitarian value to be information access, flow, and interactivity, whereas the antecedents of hedonic value are flow, interactivity, and telepresence. Utilitarian and hedonic values both positively affect the user visit intention. These results provide key understandings to enable the adoption of VR technology in tourism. Progressing in this field of tourism businesses, Moise, Gil-Saura, and RuizMolina [7] explore the relationships between the value of co-creation and guest trust, satisfaction, and loyalty in the context of green hotels. The results of this study reveal that guest participation in the hotel's process of value co-creation positively affects guests' 
trust, satisfaction, and loyalty. Additionally, they provide managerial implications to help hotel managers use a value co-creation to develop competitive strategies that would generate more value for tourists due to the positive effects of these strategies on tourist trust, satisfaction, and loyalty. Green Brand Equity (GBE) is another research topic addressed in this Special Issue by considering empirical experience from a systematic literature review (SLR) by Górska-Warsewicz, Dębski, Fabuš and Kováč [8], who analyze factors determining GBE according to the Preferred Reporting Items for Systematic Reviews and Meta-Analysis (PRISMA) statement. Image, trust, value, satisfaction, and loyalty appeared to be the most studied determinants of GBE. Less frequently analyzed were quality, awareness, attributes, particular promotional activities, and the fact of purchase. The results obtained are important in practical terms, showing what to consider when creating GBE in different categories of products and services.

Another point discussed by the authors in this Special Issue deals with product attributes, evaluability, and consumer satisfaction. Antonides and Hovestadt [9] analyze the determinants of consumer satisfaction with mobile phones on the basis of their perceived product attribute performance, and the disconfirmation of product attribute expectations. The empirical study included 3099 participants of Amazon Mechanical Turk. The results show that negative attribute disconfirmation has a larger effect on satisfaction than positive attribute disconfirmation, which is in line with the loss aversion theory. Although the perceived product attribute performance positively influences satisfaction, the authors find little support for the effects of perceived attribute performance being influenced by attribute evaluability. However, the findings indicate that negative attribute disconfirmation influences satisfaction to a greater extent for attributes that are relatively difficult-to-evaluate, in comparison to attributes relatively easy-to-evaluate.

In summary, the five contributions have sought to open new lines of research by extending the analysis proposals related to Brand Equity, Satisfaction, and Word of Mouth, as a form of loyalty based on theoretical, methodological, and/or empirical contributions. Advancing in the knowledge of the nature, structure, and scope of these variables with which to support marketing strategies is the challenge pursued in this Special Issue.

Author Contributions: Conceptualisation, M.E.R.-M., I.G.-S. and G.B.-C.; Methodology, M.E.R.-M., I.G.-S. and G.B.-C.; Validation, not applicable; Formal Analysis, not applicable; Investigation, M.E.R.-M. and I.G.-S.; Data Curation, not applicable; Writing-Original Draft Preparation, M.E.R.-M., I.G.-S. and G.B.-C.; Writing-Review and Editing, M.E.R.-M., I.G.-S. and G.B.-C.; Visualisation, M.E.R.-M., I.G.-S. and G.B.-C.; Supervision, M.E.R.-M., I.G.-S. and G.B.-C.; Project Administration, not applicable. All authors have read and agreed to the published version of the manuscript.

Funding: This research received no external funding.

Institutional Review Board Statement: Not applicable.

Informed Consent Statement: Not applicable.

Data Availability Statement: Not applicable.

Acknowledgments: We thank all the authors and reviewers whose contributions made this Special Issue possible and thank the Sustainability editorial office for providing valuable support throughout the process.

Conflicts of Interest: The authors declare no conflict of interest.

\section{References}

1. Donthu, N.; Gustafsson, A. Effects of COVID-19 on business and research. J. Bus. Res. 2020, 117, 284-289. [CrossRef] [PubMed]

2. Zwanka, R.J.; Buff, C. COVID-19 Generation: A Conceptual Framework of the Consumer Behavioral Shifts to Be Caused by the COVID-19 Pandemic. J. Int. Consum. Mark. 2021, 33, 58-67. [CrossRef]

3. Marketing Science Institute-MSI. Research Priorities 2020-2022; MSI: Cambridge, MA, USA, 2020.

4. Jiang, Y.; Wen, J. Effects of COVID-19 on hotel marketing and management: A perspective article. Int. J. Contemp. Hosp. Manag. 2020, 32, 2563-2573. [CrossRef] 
5. Marín-García, A.; Gil-Saura, I.; Ruiz-Molina, M.E.; Berenguer-Contrí, G. Sustainability, Store Equity, and Satisfaction: The Moderating Effect of Gender in Retailing. Sustainability 2021, 13, 1010. [CrossRef]

6. Lee, W.-J.; Kim, Y.H. Does VR Tourism Enhance Users' Experience? Sustainability 2021, 13, 806. [CrossRef]

7. Moise, M.S.; Gil-Saura, I.; Ruiz-Molina, M.-E. Implications of Value Co-Creation in Green Hotels: The Moderating Effect of Trip Purpose and Generational Cohort. Sustainability 2020, 12, 9866. [CrossRef]

8. Górska-Warsewicz, H.; Dębski, M.; Fabuš, M.; Kováč, M. Green Brand Equity_Empirical Experience from a Systematic Literature Review. Sustainability 2021, 13, 11130. [CrossRef]

9. Antonides, G.; Hovestadt, L. Product Attributes, Evaluability, and Consumer Satisfaction. Sustainability 2021, 13, 12393. [CrossRef] 